\title{
Air pollution from natural and anthropic sources and male fertility
}

\author{
Joanna Jurewicz ${ }^{1 *}$, Emila Dziewirska ${ }^{1}$, Michał Radwan $^{2,3}$ and Wojciech Hanke ${ }^{1}$
}

\begin{abstract}
Exposure to air pollution has been clearly associated with a range of adverse health effects, including reproductive toxicity. However, a limited amount of research has been conducted to examine the association between air pollution and male reproductive outcomes, specially semen quality. We performed a systematic review (up to March 2017) to assess the impact of environmental and occupational exposure to air pollution on semen quality. Epidemiological studies focusing on air pollution exposures and male reproduction were identified by a search of the PUBMED, MEDLINE, EBSCO and TOXNET literature bases. Twenty-two studies were included which assess the impact of air pollutants $\left(\mathrm{PM}_{2.5}, \mathrm{PM}_{10}, \mathrm{SO}_{2}, \mathrm{NOx}, \mathrm{O}_{3}, \mathrm{PAHs}\right.$ ) on main semen parameters (sperm concentration, motility, morphology), CASA parameters, DNA fragmentation, sperm aneuploidy and the level of reproductive hormones. The number of studies found significant results supporting the evidence that air pollution may affect: DNA fragmentation, morphology and motility. In summary, most studies concluded that outdoor air pollution affects at least one of the assessed semen parameters. However the diversity of air pollutants and semen parameters presented in the studies included in the review and different study design caused lack of consistency in results and difficulties in comparison.
\end{abstract}

Keywords: Air pollution, Environmental exposure, Occupational exposure, Semen quality, Male fertility

\section{Introduction}

During the past decades a possible degradation in human semen quality has been debated intensively and has become an important public health issue. A controversial review article of 61 studies analyzing sperm concentrations in fertile men and in men of unknown fertility published between 1938 and 1990 by Carlsen et al., 1992 showed a significant decrease in sperm concentrations (from $113 \mathrm{mln} / \mathrm{ml}$ to $66 \mathrm{mln} / \mathrm{ml}$ ) and in semen volume (from $3.40 \mathrm{ml}$ to $2.75 \mathrm{ml}$ ) [1]. Critics suggested that changing laboratory methods, statistical issues, heterogenicity of populations selected for studies (men of proven fertility or not, different geographical regions and ethnic groups), bias because of factors such as age and abstinence time or inherent variability of sperm counts might have affected the findings [2-4]. However more recent analysis gives further evidence for declining sperm quality. Swan et al., 2000 performed multivariate analysis of

\footnotetext{
* Correspondence: joanna.jurewicz@imp.lodz.pl

${ }^{1}$ Department of Environmental Epidemiology, Nofer Institute of Occupational Medicine, 8 Teresy St, 91-362 Lodz, Poland

Full list of author information is available at the end of the article
}

101 studies from 1934 to 1996, taking into account many of the confounding factors, reported an even greater reduction in sperm concentration, indicating an annual decline of $1.5 \%$ in the USA compared with the $1 \%$ previously determined by Carlsen et al., 1992 [5].

Over time the World Health Organization has lowered the accepted values for normal semen parameters (count, motility and morphology) because in the last decades those parameters have consistently decreased even in healthy men [6]. It has been suggested that this decrease in semen quality is associated with the observed decrease in fertility [7].

This has raised new concerns about environmental factors such as exposure to pollutants or toxicants, and lifestyle factors such as smoking, heat, stress, obesity and sexual behaviours which might affect human fertility [8-11].

Air pollutants can be in the form of solid particles, liquid droplets, or gases. In addition, they may be natural or man-made. Sources of air pollution refer to the various locations, activities or factors which are responsible for the releasing of pollutants into the atmosphere. Particulate matter $(\mathrm{PM})$ in the respirable range $\left(\mathrm{PM}_{2.5}\right)$ is of

(C) The Author(s). 2018 Open Access This article is distributed under the terms of the Creative Commons Attribution 4.0 International License (http://creativecommons.org/licenses/by/4.0/), which permits unrestricted use, distribution, and 
particular interest, because it can carry multiple trace elements and polycyclic aromatic hydrocarbons (PAHs), a group of compounds that include several endocrine disruptors which may affect both the hypothalamic pituitary axis and testicular spermatogenesis and have the potential for causing sperm alterations $[12,13]$.

Ambient air pollution has been associated with a variety of health effects including cardiovascular [14] and respiratory diseases [15], adverse pregnancy outcome or impaired neurodevelopment in children [16]. However, a limited amount of research has been conducted to examine the association between air pollution and male reproductive outcomes, specifically semen quality.

The aim of this review was to assess current evidence regarding the impact of air pollution on male fertility.

\section{Materials and methods}

Epidemiological studies focused on the exposure to air pollution and male fertility were identified by a search of the PubMed, Medline and Ebsco literature databases (before March 2017). The search combined terms referring to outdoor air pollution and male fertility. The combination of following key words was used: 1 ) referred to the exposure: exposure to air pollutants: $\mathrm{PM}_{2.5}, \mathrm{PM}_{10}, \mathrm{SO}_{2}, \mathrm{NOx}, \mathrm{O}_{3}$, polycyclic aromatic hydrocarbons (PAHs); 2) referred to outcome: main semen parameters (sperm concentration, motility, morphology), CASA (Computer-Assisted Sperm Analysis) parameters (VAP (average path velocity), VSL (straight velocity), VCL (curvilinear velocity), ALH (amplitude of lateral displacement of the sperm head, LIN (linearity), BCF (beat-cross frequency), STR (path straightness), DNA fragmentation, sperm aneuploidy and the level of reproductive hormones.

From each study, the following information was abstracted: authors, the year published, the year studied, study design, population demographics, results, the main conclusions, exposure and methods used for its assessment (including biomarkers) and confounding factors. We included cohort, case-control and cross-sectional studies that analyzed the impact of outdoor air pollutants on male fertility in humans. The studies with exposure to most commonly assessed air pollutants: $\mathrm{PM}_{2.5}$, $\mathrm{PM}_{10}, \mathrm{SO}_{2}, \mathrm{NOx}, \mathrm{O}_{3}, \mathrm{PAHs}$ were included. As just a few studies evaluated different air pollutants e.g. lead or cadmium those studies were not included in the present review. We excluded studies that analyzed the effects of air pollution on pregnancy outcome as well as those assessing the effects of lifestyle factors (smoking, alcohol consumption, caffeine intake). Also studies focused on animal research, in vitro studies and review papers were excluded. We limited the language only to English and we included only peer-review original articles.
Data were independently extracted by two investigators, who determined eligibility. Discrepancies were resolved by intervention of a third independent author. If multiple published reports from the same study were available, only the one with the most detailed information was included. All pertinent reports were retrieved and the relative reference lists were systematically searched in order to identify any potential additional studies that could be included.

\section{Results}

In our initial search (up to March 2017) a total of 250 studies were retrieved in the initial electronic search. Of these, 210 were excluded by abstract because were focused on the animal research, were concentrated on molecule level or the study was a review according to the exclusion criteria described above, leaving 30 articles for inclusion in our analysis. Nine of the studies were excluded because the full text was not in English and because it was a review article or meta-analysis. The total of 22 articles were included. Remaining articles were excluded because did not assess outdoor air pollution (mainly indoor air pollution). Details of the studies included in the review are presented in Table 1.

\section{Summary of collected data \\ Environmental exposure to air pollutants \\ Main semen parameters (motility, morphology, sperm concentration)}

Thirteen studies examine the association between main semen parameters and environmental outdoor air pollution [17-29]. Three studies were performed in USA [18-20], five in China [21, 22, 27-29] and two in Poland $[23,24]$ and in Czech Republic $[17,26]$ and one in Italy [25]. In six of the presented studies the study population was recruited from general population $[17,19,21,22,25$, 26]. The level of PAHs were analyzed in four studies $[22,24,28,29]$ in urine $[24,28,29]$ and blood [22].

In the study performed in Czech Republic the authors noticed that men exposed to air pollution were more likely to have lower percentage of motile sperm $(\beta=-8.12$; 95\%CI: $-12.95,-3.30)$ and lower percentage of sperm with normal morphology $(\beta=-0.84 ; 95 \% \mathrm{CI}:-1.15,-0.53)$ (fewer sperm with normal morphology or normal head shape) than were those lived in a city with less air pollution [17]. Later study among the same participants did not find the association between high air pollution and sperm concentration, volume, motility and morphology [26]. The Authors concluded that the inconsistency between studies could be due to differences in the exposures.

In the study in Los Angeles, California environmental exposure to ozone $\left(\mathrm{O}_{3}\right)$ was associated with lower sperm concentration $(p<0.01)$ [18]. The ozone exposure was also associated with decrease in sperm concentration 


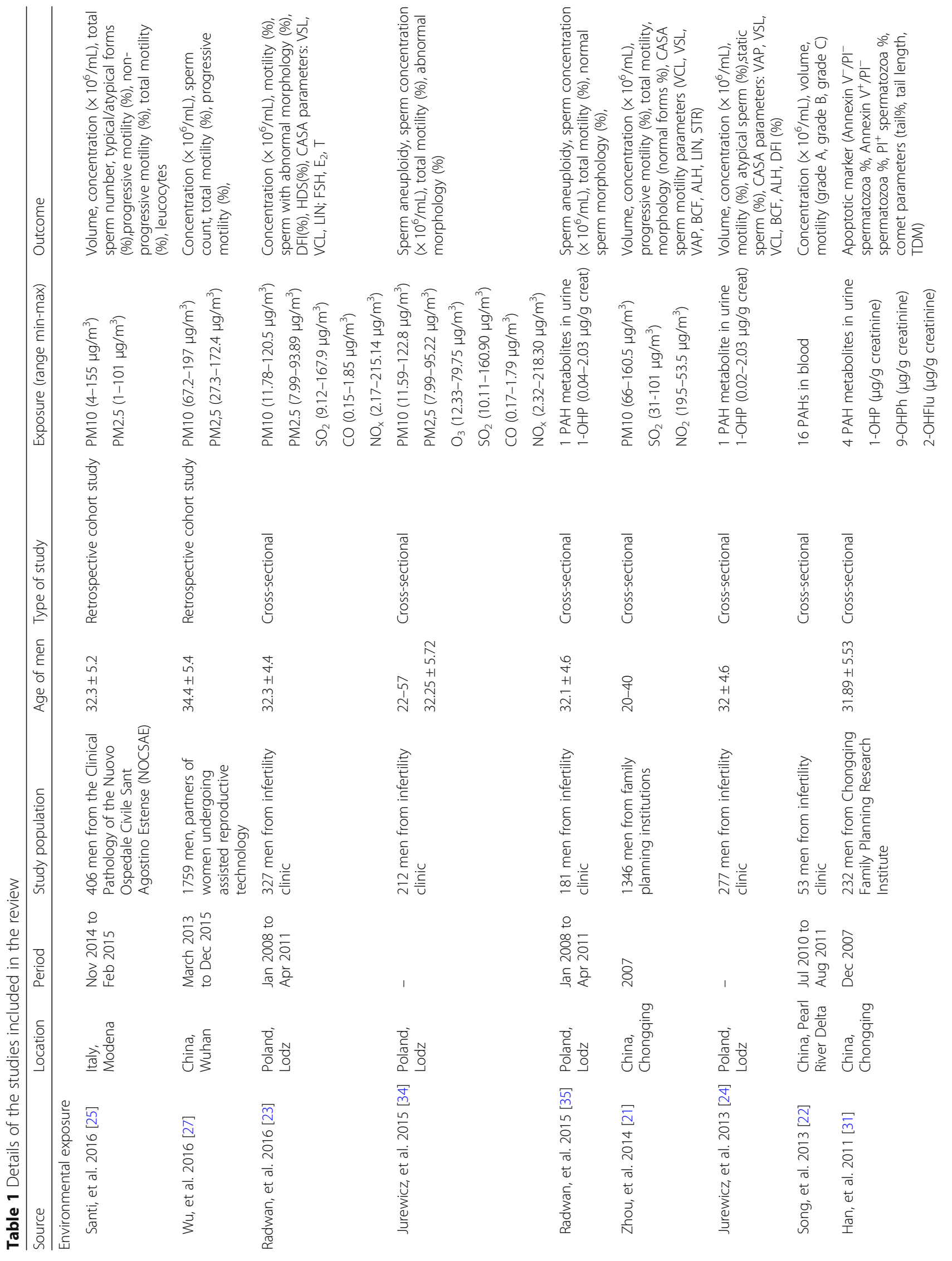




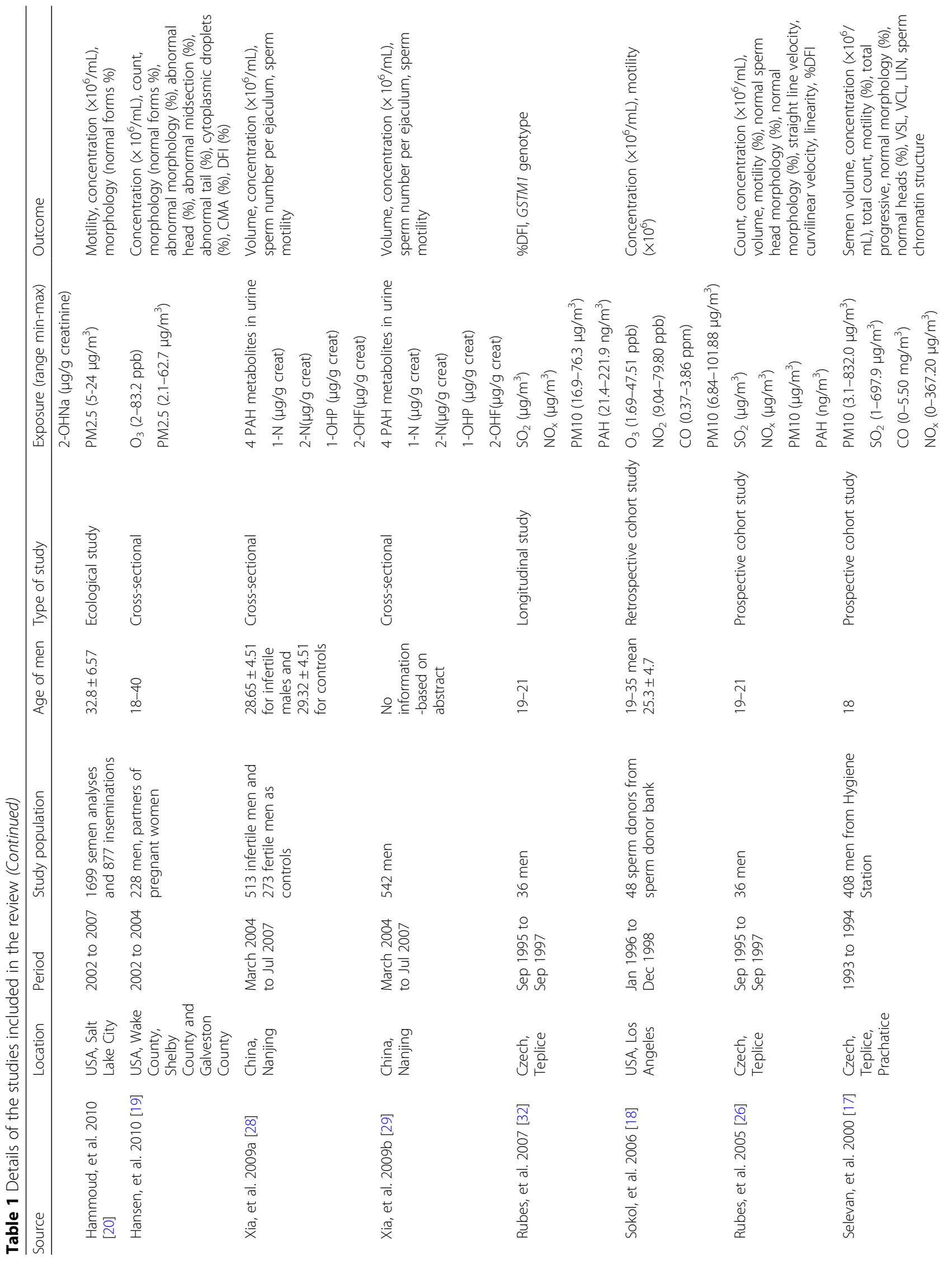




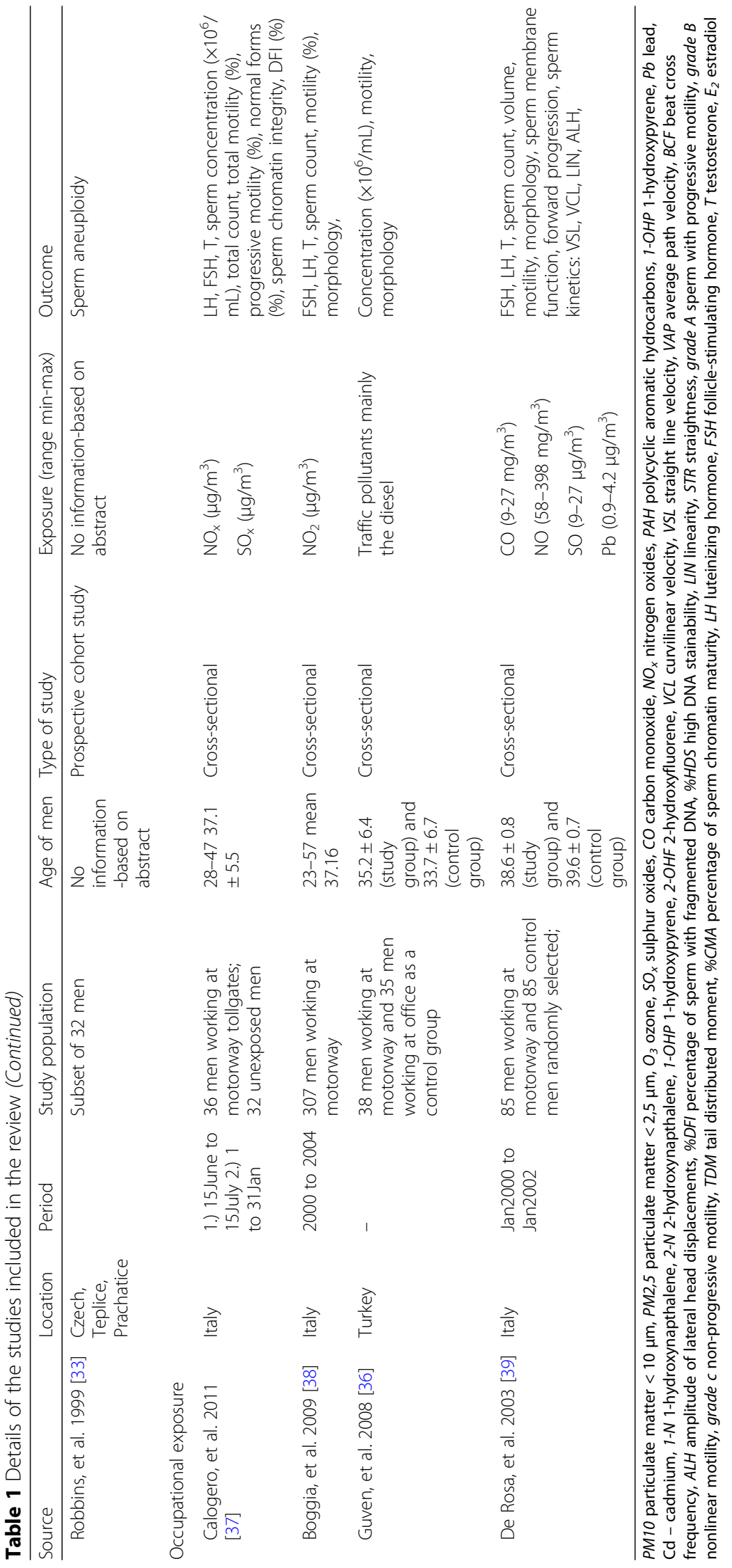


and count. Whereas exposure to $\mathrm{PM}_{2.5}$ increase the percentage of sperm cells with cytoplasmic drop and abnormal heads (but only in basic model without adjusting for potential confounding factors) in the study performed in United States by Hansen and co-workers (2010) [19]. Hammoud et al., 2010 in study conducted in Salt Lake City, Utah, found a negative association between $\mathrm{PM}_{2.5}$ and sperm motility and sperm head morphology $(p=0.010$ and $p=0.044$ respectively) [20].

In urban and rural areas in China the study performed among 1346 volunteers observed that the concentration of $\mathrm{PM}_{10}, \mathrm{SO}_{2}$ and $\mathrm{NO}_{2}$ were negatively associated with normal sperm morphology percentage $(p<0.001)$ [21]. The next study in China noticed a significant negative relation between semen motility and the concentration of PAHs (polycyclic aromatic hydrocarbons) in blood among 53 infertile volunteers $(p<0.01)$ [22]. The next study among 1759 men undergoing assisted reproductive technology procedures also performed in China found that exposure to $\mathrm{PM}_{2.5}$ was inversely associated with sperm concentration $(\beta=-0.20$; (95\%CI: $-0.34,-0.07)$ and count $(\beta=-0.22$; 95\%CI: $-0.35,-0.08)$ [27].

Santi et al., 2016 in Italian study observed that $\mathrm{PM}_{2.5}$ was directly related to total sperm number $(p<0.001)$. $\mathrm{PM}_{10}$ was directly related to both semen volume $(0<$ $0.001)$, and typical forms $(\mathrm{p}<0.001)$, inversely related to atypical forms $(\mathrm{p}<0.001)$, but related neither to sperm concentration $(p=0.430)$ nor to sperm motility [25]. Also Radwan et al., 2016 observed statistically significant association between abnormalities in sperm morphology and exposure to air pollutants $\left(\mathrm{PM}_{10}, \mathrm{PM}_{2.5}, \mathrm{SO}_{2}, \mathrm{NO}_{\mathrm{X}}\right.$, CO) $(p=0.0002, p=0.0001, \mathrm{p}=0.0001, p=0.01, \mathrm{p}=$ 0.0001 , respectively) [23]. Additionally exposure to $\mathrm{PM}_{10}, \mathrm{PM}_{2.5}, \mathrm{CO}$ was negatively associated with the level of testosterone $(p<0.05)$ [23]. The next study performed in Poland among the same men from infertility clinic examined the association between a biomarker of exposure to polycyclic aromatic hydrocarbons (1-hydroksypyrene (1-OHP)) and semen quality [24]. A positive relation was found between the level of 1-OHP in urine and sperm neck abnormalities $(p=0.001)$ as well as the percentage of static sperm cells and the level of 1-OHP decreased semen volume and motile sperm cells $(p=$ 0.018) [24]. Human studies among patients from infertility clinics in China showed that subjects with higher urinary concentrations of 1-OHP, 2-hydroxyfluorene (2-OHF) and sum PAH metabolites (assessed as tertiles) were more likely to have idiopathic male infertility ( $p$-value for trend $0.034,0.022$ and 0.022 , respectively) [28]. Higher idiopathic infertility risk was found in the group of idiopathic infertile subjects with abnormal semen quality when two groups of idiopathic infertile subjects with different semen quality [28]. In the next study by the same authors Xia et al., 2009b was found that men with higher 1-OHP (assessed as quintiles) were more likely to have below-reference sperm concentration and sperm number per ejaculum [29].

\section{CASA parameters}

The CASA parameters were assessed only in 5 studies $[17,21,23,24,26]$ this is probably because of the fact that CASA has not been applied widely in field studies because the logistics of recording the sample promptly (to avoid degradation of sperm motility over time) and controlling the temperature precisely are challenging in the field studies [30]. Zhou and co-workers 2014 observed inverse associations between sperm VCL (curvilinear velocity) and VSL and the $\mathrm{PM}_{10}, \mathrm{SO}_{2}, \mathrm{NO}_{2}(p<$ 0.001) [21]. Whereas Selevan et al., 2000 did not demonstrate any consistent negative associations between the quality of sperm motion and periods of high air pollution [17]. Rubes et al., 2005 in the same study population also did not observe any statistically significant association [26]. No association between CASA parameters: VSL, VCL, LIN and exposure to $\mathrm{PM}_{10}, \mathrm{PM}_{2.5}, \mathrm{SO}_{2}, \mathrm{NO}_{\mathrm{X}}$, $\mathrm{CO}$ [23] and the level of 1-OHP in urine [24] was also noticed the in the study performed in Poland.

\section{DNA fragmentation}

Seven studies assess the exposure to air pollution and sperm chromatin structure [17, 19, 23, 24, 26, 31, 32]. Two of them $[24,31]$ assess the exposure to polycyclic aromatic hydrocarbons, using biomarkers of exposure. In most of the studies SCSA method was used to evaluate sperm DNA, only Han et al., 2011 [31] used TUNEL method. Men exposed to air pollution in Teplice region (Czech Republic) had more sperm with abnormal chromatin than those lived in a Prachatice with less air pollution $(p<0.05)$ [17]. In the group of the same men from Teplice, high air pollution exposure was associated with increased sperm DNA fragmentation $(\beta=0.19$; $95 \% \mathrm{CI}$ : $0.02-0.36)[26]$. The next study performed by the same authors found an evidence for a gene-environment interaction between glutathione-S transferase M1 (GSTM1) and air pollution (presumably c-PAHs) [32]. This study revealed a statistically significant association between GSTM1 null genotype and increased percentage of sperm with fragmented DNA (\%DFI) $(\beta=0.309 ; 95 \%$ CI: 0.129 , 0.489) [32]. Furthermore, GSTM1 null men also showed higher \%DFI in response to exposure to intermittent air pollution (beta $=0.487$; $95 \%$ CI: $0.243,0.731$ ) [32].

The association between urinary polycyclic aromatic hydrocarbon metabolites and sperm DNA damage was examined among 232 men from general population in China [31]. The increased urinary 2-hydroxynaphthalene (2-OHNa) levels were associated with increased comet parameters including the percentage of DNA in the tail (\%tail), tail length and tail distribution $(\beta=13.26 \%$; 
95\%CI: 7.97-18.55; $\beta=12.25 ; 95 \% \mathrm{CI}: 0.01-24.52 ; \beta=$ 7.55; 95\%CI: $1.28-18.83$ respectively). Whereas the urinary level of 1-hydroxypyrene was associated only with increased tail\% ( $\beta=5.32$; 95\%CI: $0.47-10.17)$ [31]. In the study in Poland Radwan et al., 2016 found that exposure to $\mathrm{PM}_{2.5}$ and $\mathrm{PM}_{10}$ increase the percentage of cells with immature chromatin (HDS) $(p=0.002, p=0.0001$, respectively), but no the DNA fragmentation index (DFI) [23]. Whereas in the study in the same population urinary levels of 1-OHP was not associated with DNA fragmentation index in sperm (DFI) [24]. Also Hansen and co-worker 2010 did not observe any statistically significant relation between $\mathrm{PM}_{2.5}$ and $\mathrm{O}_{3}$ and DNA integrity and chromatin maturity [19].

\section{Sperm aneuploidy}

The first study which examined the association between exposure to air pollution and sperm aneuploidy was performed by Robbins et al., 1999 who collected a subset of samples $(n=32)$ from a larger epidemiological investigation of air pollution and reproductive health [33]. The sex chromosomal aneuploidy, YY, was found to be five-fold higher in sperm following periods of exposure to high air pollution (as indicated by $\mathrm{SO}_{2}$ levels $=196.9$ $\mathrm{mug} / \mathrm{m} 3)$ as compared to low exposure $\left(\mathrm{SO}_{2}=32.0\right.$ $\mathrm{mug} / \mathrm{m} 3)(\mathrm{IRR}=5.25,95 \% \mathrm{CI}: 2.5,11.0)$ [33].

The study with larger sample size of 212 men who were attending an infertility clinic for diagnostic purposes in Poland found positive associations between exposure to $\mathrm{PM}_{2.5}$ and disomy $\mathrm{Y}(p=0.001)$, sex chromosome disomy $(p=0.05)$ and disomy $21(p=0.03)$. Exposure to $\mathrm{PM}_{10}$ was associated with disomy $21(p=0.02)$ [34]. Conversely, exposure to ozone, $\mathrm{CO}, \mathrm{SO}_{2}$, and $\mathrm{NOx}$ did not affect sperm aneuploidy [34]. The study performed among the same study population observed that level of 1-OHP in urine increase the total sex-chromosome disomy $(\mathrm{p}=0.03)$ and chromosome-18 disomy ( $\mathrm{p}=0.03)$ [35].

On the other hand Rubes et al., 2005 did not find any association between exposure to periods of high air pollution and total aneuploidy among young men from Teplice [26].

\section{Occupational exposure to air pollutants \\ Main semen parameters (motility, morphology, sperm concentration)}

One of the study which investigate the effects of traffic pollutants, mainly the diesel exposure on semen parameters was performed in Turkey among 38 men working as toll collectors at motorways and 35 men working as office personnel [36]. The differences regarding the abnormal sperm count and motility were significant between the groups ( $p=0.002$ and $p=0.003$, respectively). Similarly, the ratio of sperm cells with normal morphology was significantly lower in the study group than that in the control group $(p=0.001)$ [36]. The adverse role of traffic pollutants on male fertility was also investigated in the study among 36 men working at motorway tollgates and 32 unexposed healthy men [37]. Sperm concentration, total sperm count, total and progressive motility, and normal forms were significantly lower in these men compared with controls $(p<0.05)$ [37]. Also male workers, employed in a motorway company occupationally exposed to $\mathrm{NO}_{2}$ had a significant lower sperm total motility than in not exposed workers $(\mathrm{p}<0.05)$ [38]. Total motility, forward progression were significantly lower in tollgate workers versus controls in the study performed in Italy $(p<0.0001)[39]$.

\section{CASA parameters}

Only one study assess the occupational exposure to air pollution and CASA parameters [39]. Motorway tollgate workers had significantly lower the CASA parameters: VSL, VCL, LIN, ALH (amplitude of lateral head displacements) compared with age-matched men living in the same area $(\mathrm{p}<0.0001)[39]$.

\section{DNA fragmentation}

Motorway tollgate workers had a significantly higher percentage of spermatozoa with damaged chromatin and DNA fragmentation, a late sign of apoptosis, compared with controls $(p<0.001)$ in the study performed by Calogero et al., 2011 [37]. In this study the sperm DNA was evaluated using two methods: SCSA and TUNEL.

\section{Level of reproductive hormones}

Luteinizing hormone (LH), follicle-stimulating hormone (FSH), and testosterone ( $\mathrm{T}$ ) serum levels were within the normal range in tollgate workers compared to controls in the two studies performed in Italy $[37,39]$. Serum levels of LH and FSH the study performed by Calogero et al., 2011 [37] were $(2.9 \pm 0.7$ (1.9-4.5) IU/l and $4.2 \pm 1.1$ (1.97.1) IU/l for cases and $3.2 \pm 1.1(1.5-6.5) \mathrm{IU} / \mathrm{l}$ and $4.3 \pm 1.5$ (2.4-7.1) IU/l for controls respectively). Whereas in the second Italian study the levels of reproductive hormones were as follows: $\mathrm{LH}$ (IU/l) $2.8 \pm 0.2(0.7-8.9)$ for cases 2.8 $\pm 0.1(0.9-5.4)$ for controls, FSH and serum testosterone $(\mu \mathrm{g} / \mathrm{l}) 4.1 \pm 0.3(0.7-13.5)$ and $4.8 \pm 0.2(2.3-9.2)$ respectively for cases and $3.2 \pm 0.2(0.9-6.3)$ and $4.7 \pm 0.2$ (2.9-10.8) respectively for controls [39].

\section{Discussion}

This review shows that air pollution (environmental and occupational) may affect semen quality. All the papers included in the review reported significant association with at least one of the examined semen parameters (Table 2). Number of studies found a significant results supporting the evidence that air pollution may affect: DNA fragmentation, morphology and motility. 


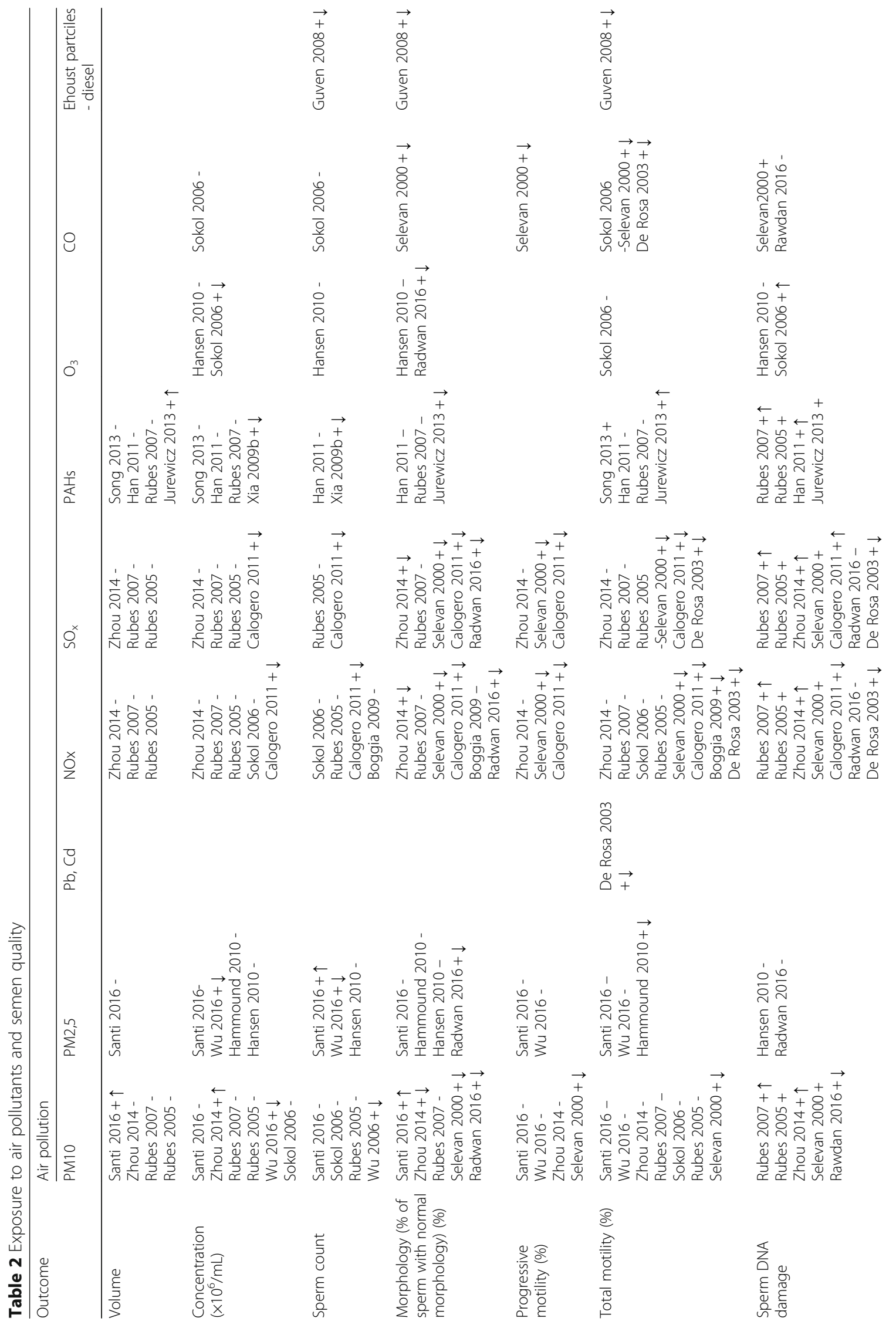


Jurewicz et al. Reproductive Biology and Endocrinology

(2018) 16:109

Page 9 of 18

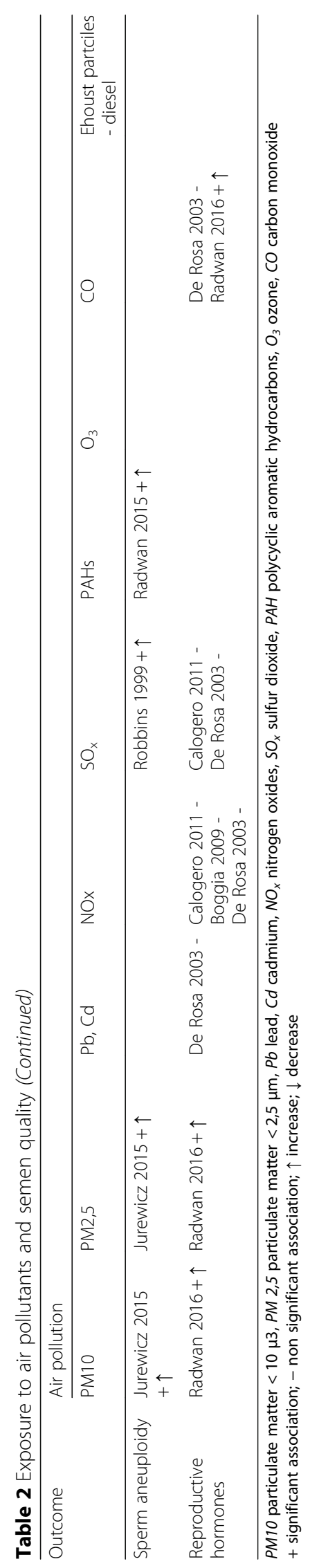


Other review studies on exposure to air pollutants and male fertility also indicated the link between air pollution and sperm motility [40], sperm DNA fragmentation and morphology [41]. Deng et al., 2016 [42] in the meta-analyis found an evidence that ambient air polluation could alter sperm parameters resulting in infertility. Additionally several animal toxicological studies have provided evidence that exposure to air pollutants could damage the testicles and impact on sperm quality and fertility [43].

\section{Adjustment for confounders}

Details of the potential risk factors are shown in Table 3. The results of the presented studies were adjusted for well-known confounders such as abstinence period (days before semen collection), age, smoking status and drinking. In some studies the smoking status was confirmed by the measure of the cotinine level in saliva or urine $[23,24,34]$. Several studies also considered the caffeine intake [17], season [17, 23, 24, 26, 34], temperature [18], BMI $[19,21]$ and ethnicity $[18,19]$. Other factors were adjusted in some studies, such as vitamin [19], past diseases [23, 24, 34] and work posture [38].

The major potential confounders in studies of exposure to air pollution and semen quality are well-known and most studies at least try to assess them. The concern is generally in the factors which are unmeasured such as stress or family support. Although available confounders were taken into account in the statistical analysis there is still possibility that residual or unmeasured confounding factors partly contributed to the observed association.

\section{Assessment of exposure}

In most of the presented studies the exposure assessment was based on the information from monitoring stations for a specific period of time (90 days) before semen sampling (Table 1). Arithmetic mean for period of 90 days before semen collection was calculated as indicator of exposure. The process of spermatogenesis involves a series of complex steps (stem cell replication, meiosis, and spermiogenesis) over approximately 74 days in humans [44]. An exposure period of approximately 90 days is generally accepted as being of sufficient duration for detecting effects on any stage of spermatogeneis when using semen measures as the biologic end points [17].

The biomarkers of exposure was used in 6 of the presented studies. One of those studies were conducted in occupational settings and measured lead in the blood and methemoglobin as a marker of $\mathrm{NO}_{2}$, sulphemoglobin for $\mathrm{SO}_{2}$, carboxyhemoglobin and zinc propophyrin. In case of environmental exposure $\mathrm{PAH}$ metabolites were measured in urine in five studies $[22,24,28,29$, 31]. Han et al., 2011 [31] and Xia et al., 2009a [28], Xia et al., 2009b [29] have assessed urinary level of four PAH metabolites whereas Jurewicz et al., 2013 [24] assessed only 1-hydroksypirene (1-OHP). Song et al., 2013 measured 16 PAHs levels in blood and semen [22].

\section{Differences in the results between studies}

There are possibly numerous factors contributing to the divergent results between the studies. The various endpoints of semen quality (sperm concentration, motility, morphology, sperm DNA damage, sperm aneuploidy) used may be a possible explanation for the different study results. The use of different biomarkers to ascertain exposure or the exposure estimation based on the information from the monitoring station may have some bearing on the statistical association. Also different level of exposure to air pollutants may impact on the differences between studies. The choice of covariates for statistical models may also impact the results. Further issue is a possibility of concomitant exposure to other environmental or occupational factors which may also have an impact on semen quality. Other potential explanations for the differences among studies include the type and timing of exposure, dose, measurement of the exposure or an outcome.

\section{Biological mechanism}

A limited number of animal toxicologic studies have provided preliminary evidence of associations between exposure to air pollutants and semen quality outcomes. Associations have been observed between total air pollution and reduced daily sperm production in mice and rats receiving in utero or prenatal exposure to total diesel exhaust and filtered exhaust [45]. The biological mechanisms linking ambient air pollution to decreased sperm quality have yet to be determined. Sokol et al., 2006 identified several possible mechanisms, including $\mathrm{O}_{3}$-induced oxidative stress, inflammatory reactions, and the induction of the formation of circulating toxic species [18]. Rubes et al., 2007 concluded that the reactive metabolites of $\mathrm{PM}_{10}$ can reach the testes and react with sperm DNA to form adducts; this toxic effect occurs in late spermatogenesis, when there are no repair mechanism to correct it, resulting in increased DNA fragmentation [32]. Additionally Hammound et al., 2010 suggest that $\mathrm{PM}_{2.5}$ could act as an endocrine disruptor affecting late synthesis of proteins necessary for sperm motility [20]. Additionally the reactive oxygen species damage the integrity of DNA in the sperm nucleus which may affect sperm count and motility [46, 47].

Rubes et al., 2007 found that men who are homozygous null for GSTM1 have lower capacity to detoxify reactive metabolites of carcinogenic polycyclic aromatic hydrocarbons and are consequently more susceptible to the effects of air pollution on sperm chromatin [32]. Also polymorphism in other repair genes (XRCC1, 


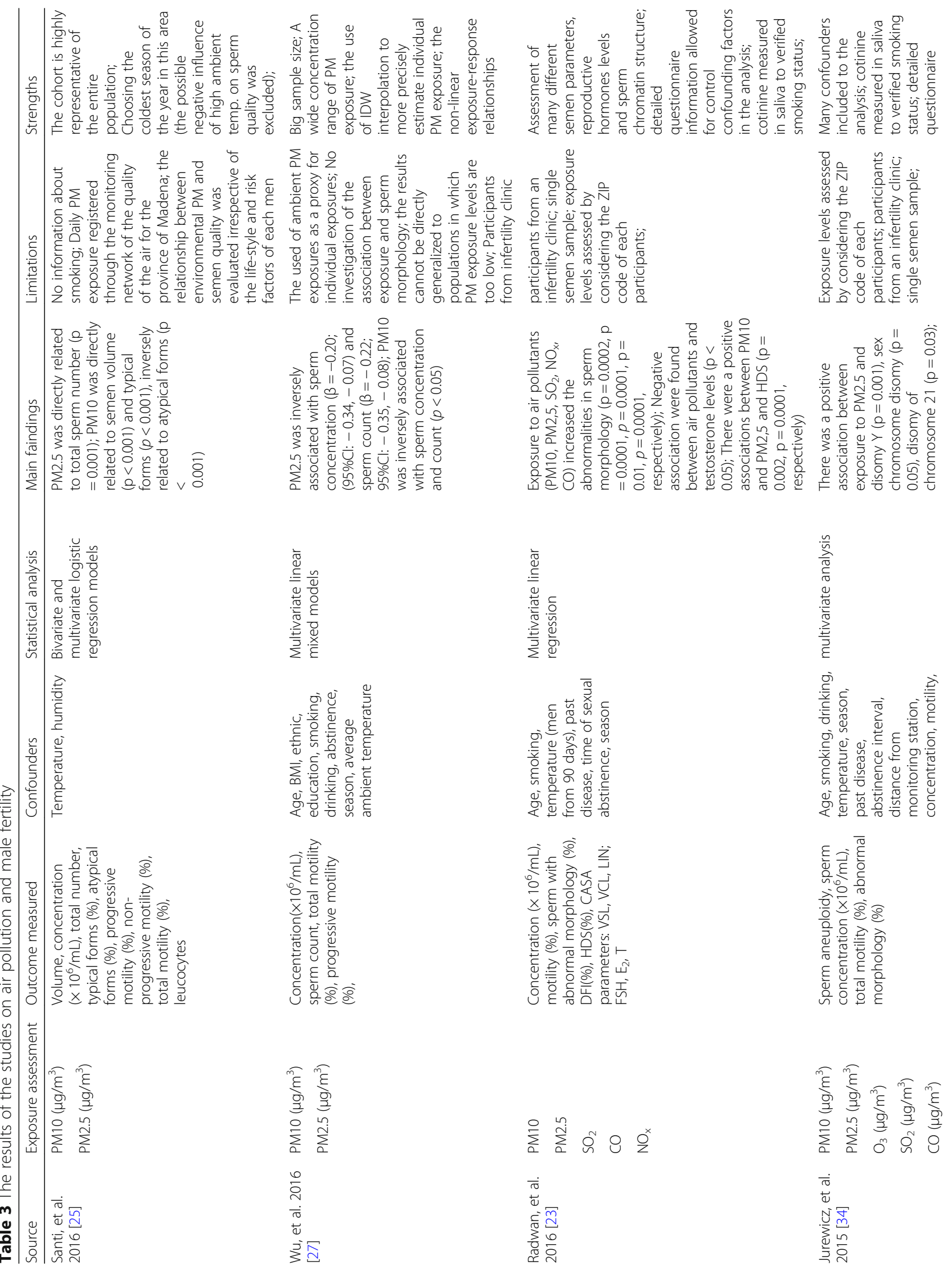




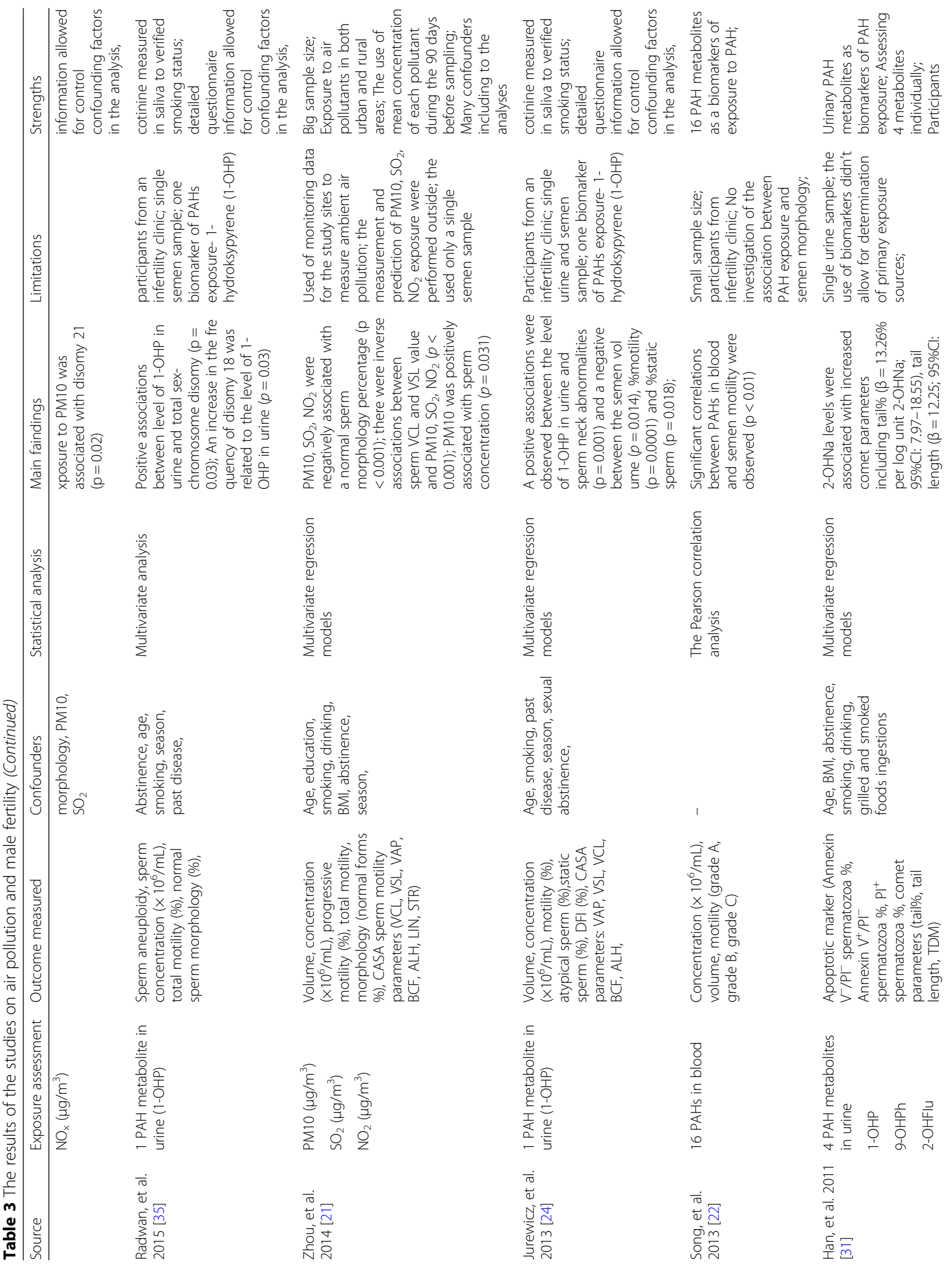




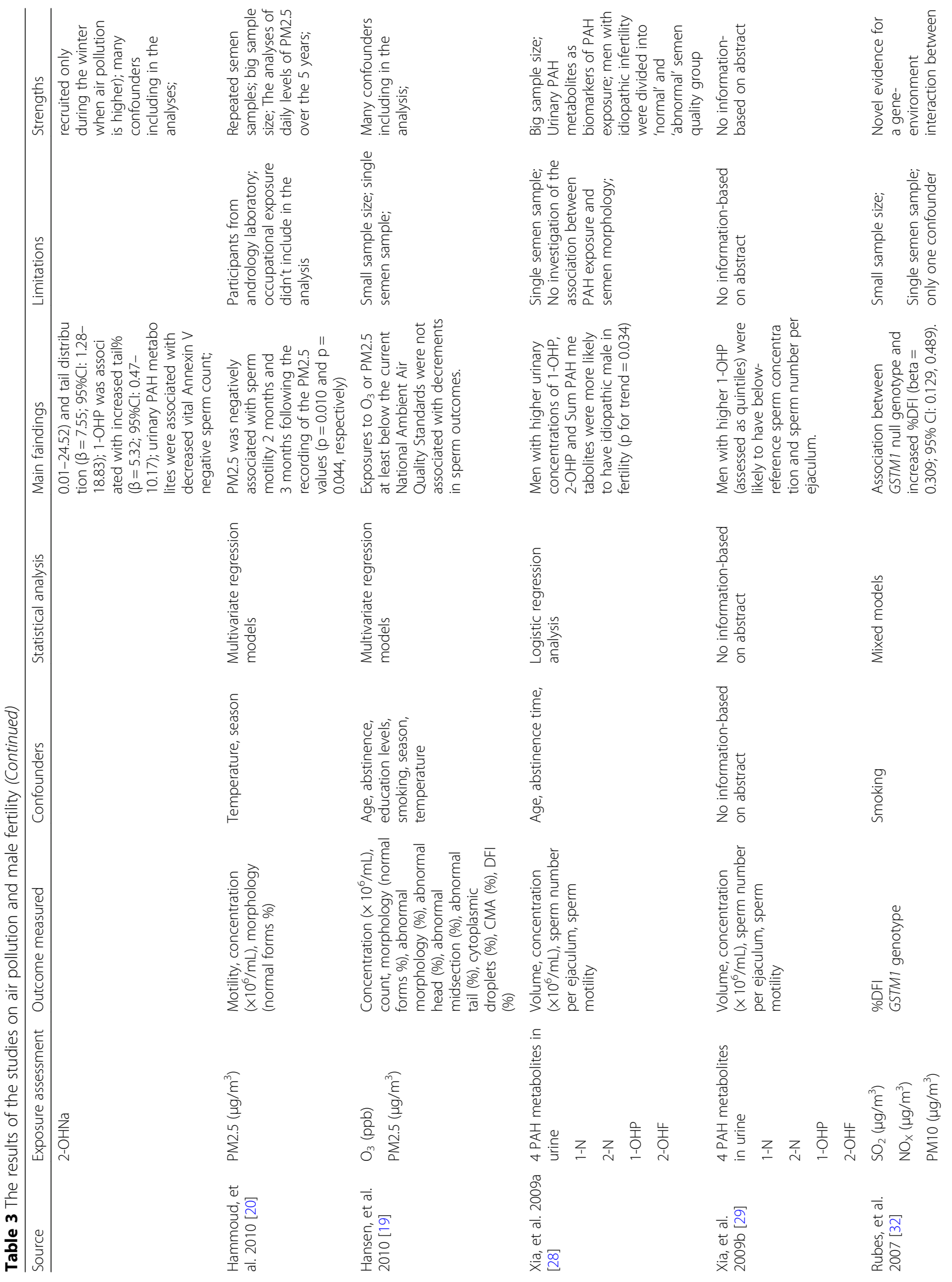




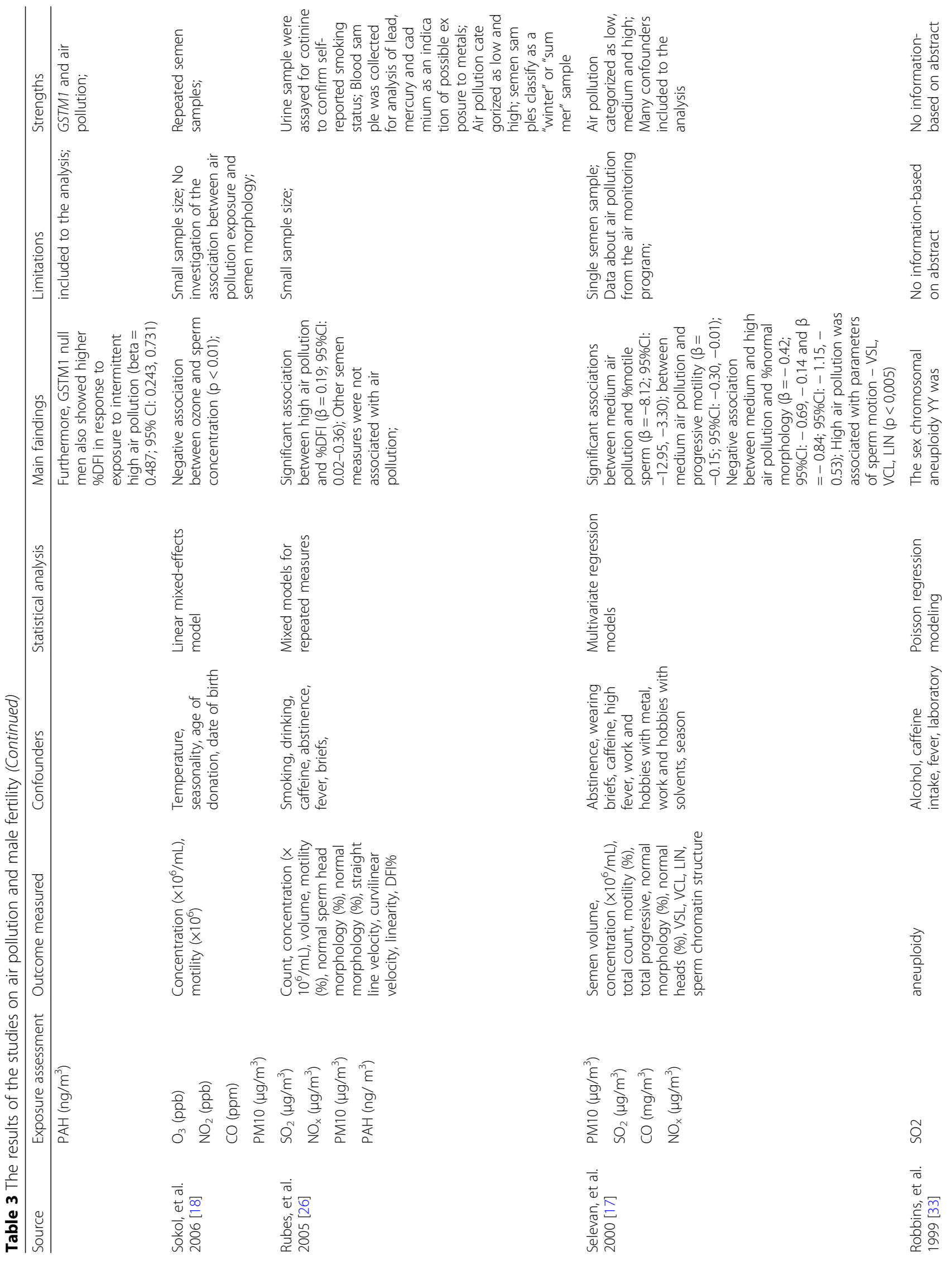




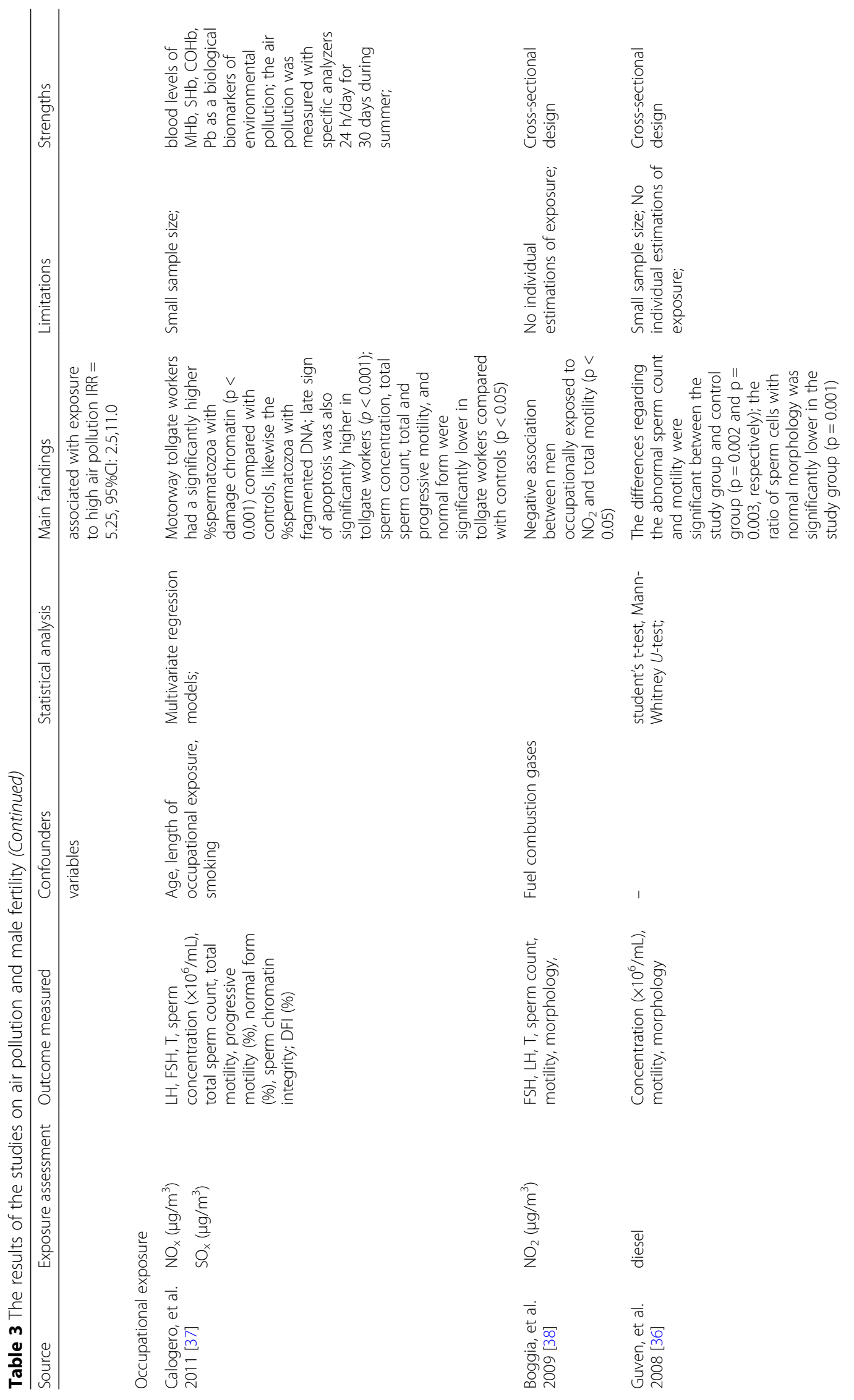




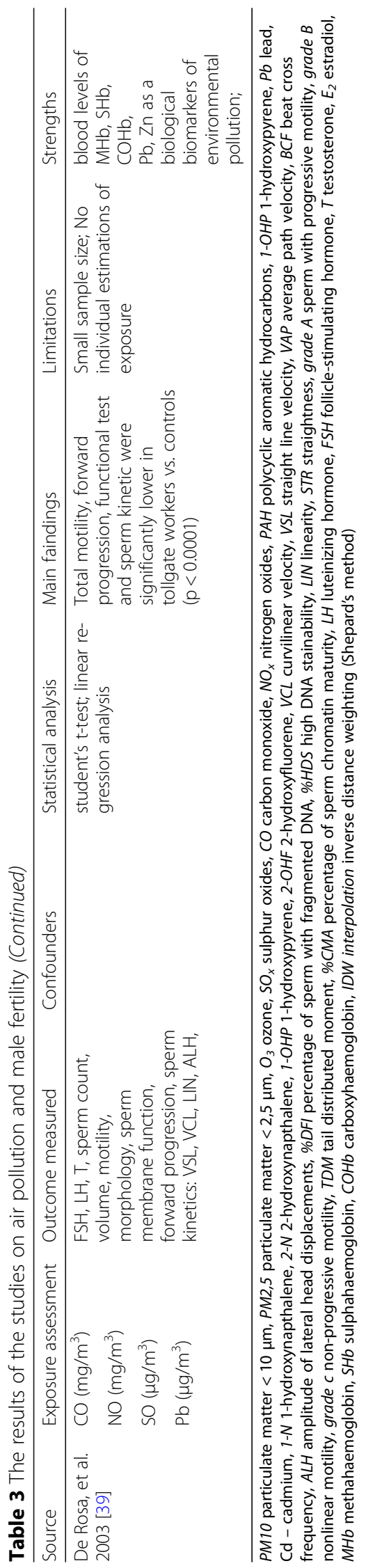


$X P D 6, X P D 23)$ and observe an association with high or medium DNA sperm damage [48].

\section{Strength and limitations of the studies}

The studies presented in this review are mostly well-design and adjusted for potential confounders (Table 3).

The limitation is the exposure assessment approach based on the information regarding air pollution from monitoring stations in the limitation in most of the reviewed studies. This is incapable of providing truly individual estimates of exposure. Individual's precise exposure to any component of air pollution would be expected to depend on his location, activity patterns and the weather conditions. Additionally in most of the studies single semen samples were collected. Only Sokol et al., 2006 [18] and Hammound et al., 2010 [20] collected multiple semen samples, which is relevant considering the known high intraindividual variability in semen quality. Also in most of the studies there is no information about co-exposure. The next limitation arise from the fact that in most of the selected studies assessing the environmental exposure examined the semen samples among men from infertility clinic.

\section{Conclusions}

In conclusion we have found that exposure to air pollution may affect semen quality, especially sperm DNA damage, morphology and motility. The diversity of the semen parameters used in the studies and different approach in exposure assessment made the comparison of the results difficult. Future research should use a better characterization of exposure models in order to validate the effects of air pollution on human sperm. Prospective studies in well-defined cohorts of men in various populations are needed to evaluate the potential effect of air pollution on male reproductive health. These studies should take into account other factors which may interfere with male reproductive health. Future studies should incorporate different seasons to generate a more accurate and full assessment of adverse effect of air pollution on male fertility.

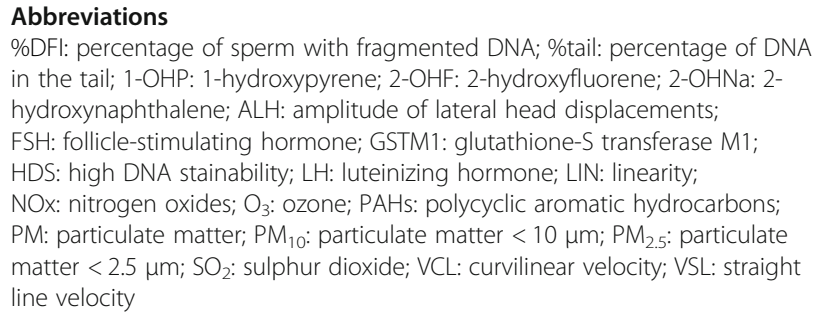

Ethic approval and consent to participate

Not applicable.

Consent for publications

Not applicable.

Availability of data and material

All data are included in this article.

\section{Founding}

We did not receive any findings for this study.

\section{Author's contributions}

$J J, E D, M R, W H$ conducted the literature searchers, selected the studies to be included and extracted the data; J drafted the manuscript. All authors provided substantial intellectual contributions and approved the final version of the manuscript.

\section{Competing interests}

The author declare that they have no competing interest.

\section{Publisher's Note}

Springer Nature remains neutral with regard to jurisdictional claims in published maps and institutional affiliations.

\section{Author details}

'Department of Environmental Epidemiology, Nofer Institute of Occupational Medicine, 8 Teresy St, 91-362 Lodz, Poland. Department of Gynecology and Reproduction, "Gameta" Hospital, 34/36 Rudzka St, 95-030 Rzgów, Poland.

${ }^{3}$ Faculty of Health Sciences, The State University of Applied Sciences in Plock, 2 Dąbrowskiego Sq, 09-402 Płock, Poland.

Received: 18 May 2017 Accepted: 24 October 2018

Published online: 23 December 2018

\section{References}

1. Carlsen E, Giwercman A, Keiding N, Skakkebaek NE. Evidence for decreasing quality of semen during past 50 years. BMJ. 1992;305:609-13.

2. Farrow S. Falling sperm quality: fact or fiction? BMJ. 1994;309:1-2.

3. Olsen GW, Bodner KM, Ramlow JM, Ross CE, Lipshultz LI. Have sperm counts been reduced 50 percent in 50 years? A statistical model revisited. Fertil Steril. 1995;63:887-93.

4. Paulsen C, Berman N, Wang C. Data from men in greater Seattle area reveals no downward trend in semen quality: further evidence that deterioration of semen quality is not geographically uniform. Fertil Steril. 1996;65:1015-20.

5. Swan SH, Elkin EP, Fenster L. The question of declining sperm density revisited: an analysis of 101 studies published 1934-1996. Environ Health Perspect. 2000;108:961-6.

6. World Health Organization. WHO laboratory manual for the examination and processing of human semen - fifth edition. 2010. http://apps.who.int/ iris/bitstream/handle/10665/44261/97892241547789_eng.pdf;jsessionid= 407AC012062B1620AE533AD2B4BA8219?sequence=1. cited 7 March 2017.

7. Skakkebaek NE, Jørgensen N, Main KM, Rajpert-De Meyts E, Leffers $H$, Andersson AM, Juul A, Carlsen E, Mortensen GK, Jensen TK, Toppari J. Is human fecundity declining? Int J Androl. 2006;29(1):2-11.

8. Sharpe RM. Lifestyle and environmental contribution to male infertility. $\mathrm{Br}$ Med Bull. 2000;56:630-42.

9. Dieterle S. Urogenital infections in reproductive medicine. Andrologia. 2008; 40:117-9.

10. Gollenberg AL, Liu F, Brazil C, Drobnis EZ, Guzick D, Overstreet JW, Redmon JB, Sparks A, Wang C, Swan SH. Semen quality in fertile men in relation to psychosocial stress. Fertil Steril. 2010;93:1104-11.

11. Paasch U, Grunewald S, Kratzsch J, Glander HJ. Obesity and age affect male fertility potential. Fertil Steril. 2010;94:2898-901.

12. Kado NY, Okamoto RA, Kuzmicky PA, Kobayashi R, Ayala A, Gebel ME, Rieger PL, Maddox C, Zafonte L. Emissions of toxic pollutants from compressed natural gas and lowsulfur diesel-fueled heavy-duty transit buses tested over multiple driving cycles. Environ Sci Technol. 2005;39:7638-49. 
13. Jeng HA, Yu L. Alteration of sperm quality and hormone levels by polycyclic aromatic hydrocarbons on airborne particulate particles. J Environ Sci Health ATox Hazard Subst Environ Eng. 2008;43:675-81.

14. R B, Stafoggia M, Raaschou-Nielsen O, Andersen ZJ, Xun WW, Katsouyanni K, Dimakopoulou K, Brunekreef B, Weinmayr G, Hoffmann B, Wolf K, Samoli E, Houthuijs D, Nieuwenhuiisen M, Oudin A, Forsberg B, Olsson D, Salomaa V, Lanki T, Yli-Tuomi T, Oftedal B, Aamodt G, Nafstad P, De Faire U, Pedersen $\mathrm{NL}$, Östenson CG, Fratiglioni L, Penell J, Korek M, Pyko A, Eriksen KT, Tjønneland A, Becker T, Eeftens M, Bots M, Meliefste K, Wang M, Bueno-deMesquita B, Sugiri D, Krämer U, Heinrich J, de Hoogh K, Key T, Peters A, Cyrys J, Concin H, Nagel G, Ineichen A, Schaffner E, Probst-Hensch N, Dratva J, Ducret-Stich R, Vilier A, Clavel-Chapelon F, Stempfelet M, Grioni S, Krogh V, Tsai MY, Marcon A, Ricceri F, Sacerdote C, Galassi C, Migliore E, Ranzi A, Cesaroni G, Badaloni C, Forastiere F, Tamayo I, Amiano P, Dorronsoro M, Katsoulis M, Trichopoulou A, Vineis P, Hoek G. Long-term exposure to air pollution and cardiovascular mortality: an analysis of 22 European cohorts. Epidemiology. 2014;25(3):368-78

15. Sava F, Carlsten C. Respiratory health effects of ambient air pollution: an update. Clin Chest Med. 2012;33(4):759-69.

16. Yorifuji T, Kashima S, Higa Diez M, Kado Y, Sanada S, Doi H. Prenatal exposure to traffic-related air pollution and child behavioral development milestone delays in Japan. Epidemiology. 2016;27(1):57-65.

17. Selevan SG, Borkovec L, Slott VL, Zudova Z, Rubes J, Evenson DP, Perreault SD. Semen quality and reproductive health of young Czech men exposed to seasonal air pollution. Environ Health Persp. 2000;108(9):887-94.

18. Sokol RZ, Kraft P, Fowler IM, Mamet R, Kim E, Berhane KT. Exposure to environmental ozone alters semen quality. Environ Health Persp. 2006; 114(3):360-5.

19. Hansen C, Luben TJ, Sacks JD, Olshan A, Jeffay S, Strader L, Perreault SD. The effect of ambient air pollution and sperm quality. Environ Health Persp. 2010;118(2):203-9.

20. Hammound A, Douglass TC, Gibson M, Sanderson M, Parker-Jones K, Peterson M. Decreased sperm motility is associated with air pollution in Salt Lake City. Fertil Steril. 2010;93(6):1875-9.

21. Zhou N, Zhihong C, Yang S, Han X, Chen G, Zhou Z, Zhai C, Ma M, Li L, Cai M, Li Y, Ao L, Shu W, Liu J, Cao J. Air pollution and decreased semen quality: a comparative study of Chongqing urban and rural areas. Environ Pollut. 2014;187:145-52.

22. Song XF, Chen ZY, Zang ZJ, Zhang YN, Zeng F, Peng YP, Yang C. Investigation of polycyclic aromatic hydrocarbon level in blood and semen quality of residents in Pearl River Delta Region in China. Environ Int. 2013;60:97-105.

23. Radwan M, Jurewicz J, Polanska K, Sobala W, Radwan P, Bochenek M, Hanke $W$. Exposure to ambient air pollution-does it affect semen quality and the level of reproductive hormones? Ann Hum Biol. 2016;43(1):1-7.

24. Jurewicz J, Radwan M, Sobala W, Brzeźnicki S, Ligocka D, Radwan P, Bochenek M, Hanke W. Association between a biomarker of exposure to polycyclic aromatic hydrocarbons and semen quality. IJOMEH. 2013;26(5):790-801.

25. Santi D, Vezzani S, Granata ARM, Roli L, De Santis MC, Ongaro C, Donati F, Baraldi E, Trenti T, Setti M, Simoni M. Sperm quality and environment: a retrospective, cohort study in a northern province of Italy. Environ Res. 2016; 150:144-53.

26. Rubes J, Selevan SG, Evenson DP, Zudova D, Vozdova M, Zudova Z, Robbins WA, Perreault SD. Episodic air pollution is associated with increased DNA fragmentation in human sperm without changes in semen quality. Hum Reprod. 2005;20(10):2776-83.

27. Wu L, Jin L, Shi T, Zhang B, Zhou Y, Zhou T, Bao W, Xiang H, Zuo Y, Li G, Wang C, Duan Y, Peng Z, Huang X, Zhang H, Xu T, Li Y, Pan X, Xia Y, Gong $X$, Chen W, Liu Y. Association between ambient particulate matter exposure and semen quality in Wuhan, China. Environ Int. 2016;98:219-28.

28. Xia Y, Zhu P, Han Y, Lu C, Wang S, Gu A, Fu G, Zhao R, Song L, Wang X. Urinary metabolites of polycyclic aromatic hydrocarbons in relation to idiopathic male infertility. Hum Reprod. 2009;24(5):1067-74.

29. Xia Y, Han Y, Zhu P, Wang S, Gu A, Wang L, Lu C, Fu G, Song L, Wang X. Relation between urinary metabolites of polycyclic aromatic hydrocarbons and human semen quality. Environ Sci Technol. 2009;43(12):4567-70.

30. Schrader SM, Chapin RE, Clegg ED, Davis RO, Fourcroy JL, Katz DF, Rothmann SA, Toth G, Turner TW, Zinaman M. Laboratory methods for assessing human semen in epidemiologic studies: a consensus report. Reprod Toxicol. 1992;6:275-95.

31. Han X, Zhou N, Cui Z, Ma M, Li L, Cai M, Li Y, Lin H, Li Y, Ao L, Liu J, Cao J. Association between urinary polycyclic aromatic hydrocarbon metabolites and sperm DNA damage: a population study in Chongqing, China. Environ Health Persp. 2011;119(5):652-7.

32. Rubes J, Selevan SG, Sram RJ, Evenson DP, Perreault SD. GSTM1 genotype influences the susceptibility of men to sperm DNA damage associated with exposure to air pollution. Mutation Res. 2007;625:20-8.

33. Robbins WA, Rubes J, Selevan SG, Perreault SD. Air pollution and sperm aneuploidy in healthy young men. Environ Epidemiol Toxicol. 1999;1:125-31.

34. Jurewicz J, Radwan M, Sobala W, Polańska K, Radwan P, Jakubowski L, Ulańska A, Hanke W. The relationship between exposure to air pollution and sperm disomy. Environ Mol Mutagen. 2015;56:50-9.

35. Radwan M, Jurewicz J, Sobala W, Brzeźnicki S, Radwan P, Jakubowski L, Hawuła W, Ulańska A, Hanke W. Human sperm aneuploidy after exposure to polycyclic aromatic hydrocarbons. Reprod Fert Develop. 2015;28(9):1376-81.

36. Guven A, Kayikci A, Cam K, Arbak P, Balbay O, Cam M. Alterations in semen parameters of toll collectors working at motorways: does diesel exposure induce detrimental effects on semen? Andrologia. 2008;40:346-51.

37. Calogero AE, La Vignera S, Condorelli RA, Perdichizzi A, Valenti D, Asero P, Carbone U, Boggia B, De Rosa N, Lombardi G, D'Agata R, Vicari LO, Vicari E, De Rosa M. Environmental car exhaust pollution damages human sperm chromatin and DNA. J Endocrinol Investig. 2011;34:139-43.

38. Boggia B, Carbone U, Farinaro E, Zarrilli S, Lombardi G, Colao A, De Rosa N, De Rosa M. Effects of working posture and exposure to traffic pollutants on sperm quality. J Endocrinol Investig. 2009;32:430-4.

39. De Rosa M, Zarrilli S, Paesano L, Carbone U, Bobbia B, Petretta M, Maisto A, Cimmino F, Puca G, Colao A, Lombardi G. Traffic pollutants affect fertility in men. Hum Reprod. 2003;18(5):1055-61.

40. Najafi TF, Roudsari RL, Namvar F, Ghanbarabadi VG, Talasaz ZH, Esmaeli M. Air pollution and quality of sperm: a meta-analysis. Iran Red Crescent Med J. 2015;17(4):e26930

41. Lafuente R, Garcia-Blaquez N, Jacquemin B, Checa MA. Outdoor air pollution and sperm quality. Fertil Steril. 2016;106(4):880-96.

42. Deng Z, Chen F, Zhang M, Lan L, Qiao Z, Cui Y, An J, Wang N, Fan Z, Zhao $X$, Li X. Association between air pollution and sperm quality: A systematic review and meta-analysis. Environ Pollut. 2016;208(Pt B):663-9.

43. Meng Z, Bai W. Oxidation damage of sulfur dioxide on testicles of mice. Environ Res. 2004;96:298-304.

44. Clermont $Y$. The cycle of the seminiferous epithelium in man. Am J Anat. 1963;112:35-51.

45. Ono N, Oshio S, Niwata Y, Yoshida S, Tsukue N, Sugawara I, Takano H, Takeda K. Prenatal exposure to diesel exhaust impairs mouse spermatogenesis. Inhal Toxicol. 2007;19:275-81.

46. Agarwal A, Saleh RA, Bedaiwy MA. Role of reactive oxygen species in the pathophysiology of human reproduction. Fertil Steril. 2003;79:829-43.

47. Aitken J, Fisher $\mathrm{H}$. Reactive oxygen species generation and human spermatozoa: the balance of benefit and risk. Bioessay. 2004;16:259-67.

48. Rubes J, Rybar R, Prinosilova P, Veznik Z, Chvatalova I, Solansky I, Sram RJ. Genetic polymorphism influence the susceptibility of men to sperm DNA damage associated with exposure to air pollution. Mutat Res. 2010;683:9-15.

\section{Ready to submit your research? Choose BMC and benefit from:}

- fast, convenient online submission

- thorough peer review by experienced researchers in your field

- rapid publication on acceptance

- support for research data, including large and complex data types

- gold Open Access which fosters wider collaboration and increased citations

- maximum visibility for your research: over $100 \mathrm{M}$ website views per year

At BMC, research is always in progress.

Learn more biomedcentral.com/submissions 